\title{
PROTEIN COMPOSITION OF RABBIT OVIDUCAL FLUID
}

\author{
STANLEY S. SHAPIRO, JERILYN P. JENTSGH AND ALLAN S. YARD
}

Hoffmann-La Roche, Inc., Nutley, New Fersey 07110, U.S.A.

(Received 4th May 1970)

\begin{abstract}
Summary. The protein composition of rabbit oviducal fluid was studied with the aid of disc gel electrophoresis and immunological techniques. While many proteins of the oviducal fluid were similar to those in the serum, some different proteins were only present in the fluid. After immunization with yeast alcohol dehydrogenase of a rabbit fitted with an oviducal fluid collecting device, antibody to the dehydrogenase was found in the serum but not in the oviducal fluid. The results of these studies on the protein composition of rabbit oviducal fluid suggest that the fluid arises from both transudation and secretion.
\end{abstract}

\section{INTRODUCTION}

There appears to be a general agreement that oviducal fluid is important for the normal development of the fertilized egg during its passage along the length of the oviduct, but this agreement becomes strained when discussion turns to the nature of the process(es) concerned with the formation of the fluid. Bishop (1957) and Sobrero (1963) state simply that oviducal fluid is a secretion. Bishop (1956) showed that it accumulates in doubly ligated rabbit oviducts, presumably against a pressure gradient. Marcus \& Saravis (1965) and Marcus (1967), on the other hand, question whether oviducal fluid results from transudation, secretory events, or both. Based on ligation experiments and limited biochemical studies, Blandau (1961) has called attention to the fact that tubal fluid is a product of the oviduct itself, with little or no fluid coming from the peritoneal cavity or uterine horns.

Early workers in the field were hampered by the lack of a good method for obtaining oviducal fluid. The development of a glass device by Hamner \& Williams $(1963,1965)$ for the convenient collection of the fluid has enabled the accumulation of sufficient quantities for closer studies.

Hamner \& Williams (1965) recorded the total protein, electrolyte and carbohydrate content of rabbit oviducal fluid, but no reports have appeared on the further analysis of these proteins. The purpose of this paper is to present a qualitative protein profile of rabbit oviducal fluid as obtained by disc gel electrophoretic and immunological studies.

\section{Blood fractions}

\section{MATERIALS AND METHODS}

Goat anti-rabbit serum, rabbit albumin, rabbit $\alpha$-globulins, rabbit $\beta$ G 
globulins and rabbit $\gamma$-globulins were obtained from Mann Research Laboratories.

\section{Double-diffusion studies}

Double-diffusion studies were performed at room temperature for 18 to $24 \mathrm{hr}$ according to the method of Marcus \& Grollman (1966) using a $0.6 \%$ agarose gel containing $0.9 \% \mathrm{NaCl}, 0.02 \mathrm{~m}$-phosphate buffer, $\mathrm{pH} 7 \cdot 3,0.01 \%$ merthiolate and $3.75 \%$ glycine.

\section{Immunoelectrophoresis}

Immunoelectrophoresis was carried out according to standard procedures (Grabar \& Williams, 1955) on glass plates $(2.5 \times 7.5 \mathrm{~cm}$ ) coated with $4.0 \mathrm{ml}$ of $0.6 \%$ agarose solutions containing 0.05 M-tris-barbital buffer (Electra HR buffer, Helena Labs), pH 8.8. Solutions of $40.0 \mu \mathrm{g}$ of rabbit serum protein, oviducal fluid protein or $15 \mu \mathrm{g}$ of the pure blood fractions in a total volume of $0.02 \mathrm{ml} 0.05 \mathrm{M}$-tris-barbital buffer, $\mathrm{pH} 8 \cdot 8$, were put into the wells. Electrophor-

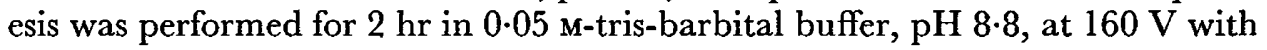
a current of $7 \mathrm{~mA}$. After electrophoresis, $0.03 \mathrm{ml}$ of antisera was put into the trough and allowed to incubate at $22^{\circ} \mathrm{C}$ for 18 to $24 \mathrm{hr}$.

\section{Immunization to yeast alcohol dehydrogenase}

One milligram of pure yeast alcohol dehydrogenase (Y-ADH) (Worthington Biochemical Corporation) was dissolved in $2 \mathrm{ml}$ of $0.15 \mathrm{~m}$-phosphate buffer, $\mathrm{pH} 7 \cdot 3$. Aliquots $(1 \cdot 0 \mathrm{ml}$ each) were injected intramuscularly into the rear leg muscles of a female rabbit equipped with an oviducal fluid collecting device (Hamner \& Williams, 1963, 1965; Yard, Juhasz \& Grimes, 1969). The injections were repeated every 4 days for 3 weeks. The rabbit was bled from the marginal ear vein or by cardiac puncture. The serum was obtained by allowing the blood to clot at room temperature. Antibody to Y-ADH gave a precipitin band in the Ouchterlony double-diffusion method (Ouchterlony, 1953) after 3 weeks of injections. The serum was stored at $-20^{\circ} \mathrm{C}$ without preservatives. Samples of serum obtained before the injection of $\mathrm{Y}-\mathrm{ADH}$ were used as controls in all experiments. This control serum had no effect on Y-ADH activity and gave no precipitin band.

\section{Alcohol dehydrogenase assay}

Activity of Y-ADH was determined by the method of Vallee \& Hoch (1955) in a total volume of $1.0 \mathrm{ml}$.

\section{Immunization to oviducal fluid}

Oviducal fluid was concentrated by ultrafiltration at $4^{\circ} \mathrm{C}$ to a final concentration of $19.0 \mathrm{mg}$ of protein/ml. Equal volumes of oviducal fluid and Freund's adjuvant containing $M$. butyricum (Difco Laboratories) were mixed thoroughly and $1.0-\mathrm{ml}$ portions were injected into the leg muscles of a hen. The injections were repeated every 4 to 5 days over a period of 10 weeks. The hen was bled from a wing vein and antibodies to oviducal fluid were detected by the Ouchterlony technique (1953) after 5 weeks. After 10 weeks, the precipitin 
bands in immunoelectrophoresis were still faint; therefore, the chicken immunoglobulins were concentrated with ammonium sulphate and dialysed against saline before use.

\section{Disc gel electrophoresis}

Polyacrylamide disc gel electrophoresis was performed according to the method of Davis (1964) with a $7.5 \%$ running gel.

\section{Protein determination}

Protein concentrations were determined by the method of Lowry, Rosebrough, Farr \& Randall (1951) using rabbit serum albumin as a standard.

\section{RESULTS}

\section{Disc gel electrophoresis}

Samples of rabbit serum and oviducal fluid subjected to disc gel electrophoresis gave similar protein patterns (Pl. 1, Fig. la, b). Albumin, $\alpha$-, $\beta$ - and $\gamma$-globulins were identified in the oviducal fluid. However, upon careful examination of the globulin fractions, reproducible differences were observed between rabbit oviducal fluid and rabbit serum. The serum had at least two additional bands in the gamma-alpha ${ }_{2}$ region when compared to rabbit oviducal fluid. In the same region, oviducal fluid showed two bands not seen in the serum. There also appeared to be an enrichment of albumin in the oviducal fluid. Densitometric tracings confirmed these differences in the protein profile of the two biological fluids (Pl. 1, Fig. la, b). Since minor protein components cannot be identified readily, the differences in the two fluids with respect to the entire population of individual proteins may be very much greater than were seen in these experiments.

\section{Immunoelectrophoresis}

To confirm the presence of serum proteins in oviducal fluid, rabbit serum and oviducal fluid were subjected to immunoelectrophoresis. Rabbit oviducal fluid reacted with commercial anti-rabbit serum to produce precipitin bands confirming the presence of serum proteins (Pl. 1, Fig. 2). Major differences in the precipitin band pattern were seen in the alpha $_{2}$-beta region. The oviducal fluid reacted with antibody to form arcs which appeared elongated when compared to the more circular arcs obtained from serum in the same region. In addition to differences in shape of the arcs, the oviducal fluid produced fewer precipitin bands in this region.

The differences in the shapes of the arcs are difficult to interpret. They may mean that the oviducal-fluid proteins are immunologically similar to serum protein (hence, cross-reactivity with antibody) but are in reality different as suggested by their electrophoretic behaviour. There is the further possibility that modification of the serum proteins may occur when they are in the oviduct or while they are moving into the oviducal lumen. The electrophoretic properties may change but not the antigenic properties. These alterations might include chemical modification, binding of small molecules or the action of 
proteolytic enzymes. At this time, we cannot account for the elongation of the oviducal fluid precipitin bands.

The lower number of precipitin bands in the oviducal fluid compared to serum is significant. This means that there are antigenic proteins in the serum which are not present in the oviducal fluid. These proteins may be completely absent from the oviducal fluid or so modified that they cannot now react with antibody. These immunoelectrophoretic studies are in agreement with the results obtained from the disc gel studies. It appears that the major proteins of rabbit oviducal fluid are from serum. However, the total protein composition of rabbit oviducal fluid is not identical to that of rabbit serum.

\section{Detection of serum proteins}

The protein fractions of the oviducal fluid were identified as either $\alpha$-, $\beta$ - or $\gamma$-globulins or albumin according to electrophoretic mobility under standard conditions. In order to show that the proteins designated as albumin in the oviducal fluid were identical to those in the serum, an immunodiffusion study was carried out with commercial preparations of rabbit serum, albumin, $\beta$-globulin and antisera (Pl. 2, Fig. 3). This showed a continuous precipitin band with albumin, serum and oviducal fluid indicating the presence of albumin in oviducal fluid as well as serum. The plate also shows the presence of $\beta$-globulins in oviducal fluid. Similar experiments were carried out with $\alpha$ - and $\gamma$-globulin, thus providing additional evidence for the identity of certain serum and oviducal fluid proteins. Immunoelectrophoresis of oviducal fluid and purified rabbit albumin provided further confirmation of the presence of albumin (Pl. 2, Fig. 4). Similar results were obtained with $\alpha$-, $\beta$ - and $\gamma$-globulins.

\section{Rabbit anti- $\Upsilon$ - $A D H$}

Evidence obtained with electrophoretic and immunoelectrophoretic techniques indicated the absence of some serum proteins in oviducal fluid. A New Zealand White female rabbit, fitted with an oviducal fluid collecting device, was immunized to Y-ADH. This protein was used because it is foreign to the rabbit, available in high purity, easily assayed, and should be antigenic in the rabbit. The resulting antibody was used to evaluate large molecule transfer. After 3 weeks, anti-Y-ADH was detected in serum by Ouchterlony doublediffusion and by inhibition of enzymatic activity. No anti-Y-ADH was detected in the oviducal fluid up to 10 weeks, even at protein levels four times that of serum (Pl. 2, Fig. 5).

Immunoglobulins as a class can be identified in oviducal fluid (Pl. 1, Fig. 2) However, generalizations on selectivity of immunoglobulins to be transferred into the oviducal fluid are not possible from these experiments, but observations made with antibody to $\mathrm{Y}-\mathrm{ADH}$ provide support for the hypothesis that not all rabbit serum proteins are found in oviducal fluid.

\section{Immunoelectrophoresis of rabbit serum and oviducal fuid with anti-rabbit oviducal fluid}

Disc gel electrophoresis gave preliminary evidence that some proteins present in the oviducal fluid are not found in serum. Antibodies prepared in the hen against rabbit oviducal fluid proteins reacted with rabbit serum (Pl. 2, 

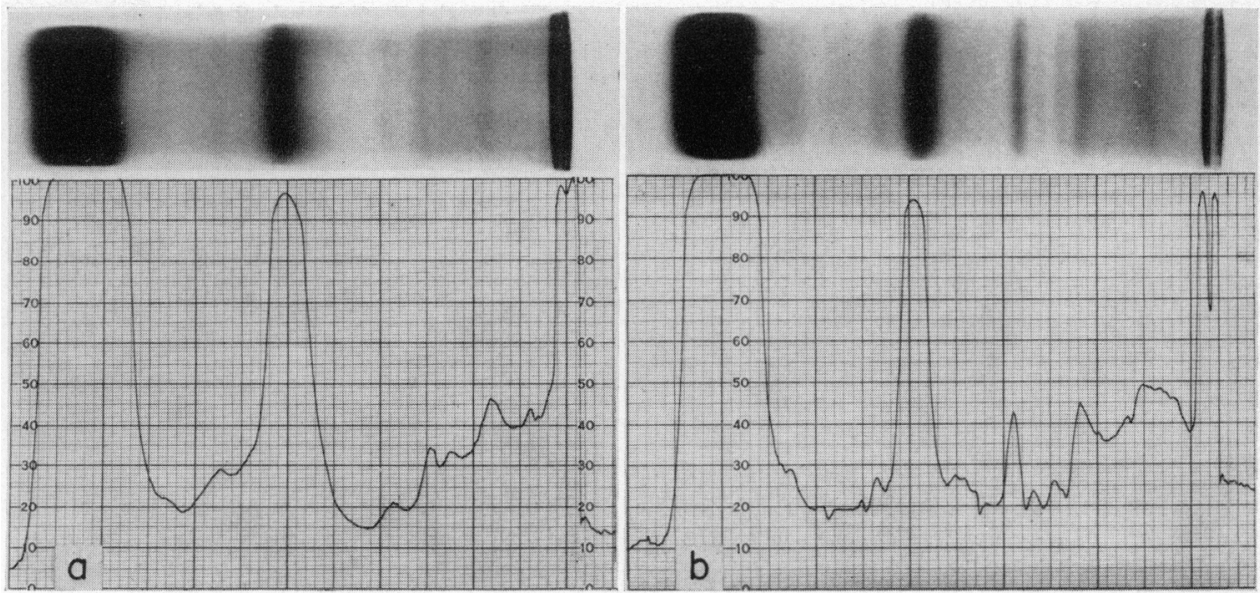

Fig. 1. Disc gel electrophoresis of rabbit oviducal fluid and rabbit serum. Conditions for the disc gel electrophoresis are described under Methods. Densitometric tracings of the gels were obtained with a Photovolt Densitometer: (a) Rabbit oviducal fluid, $20 * \mu 1$ sample applied and (b) rabbit serum, 1.5- $\mu$ l sample applied.

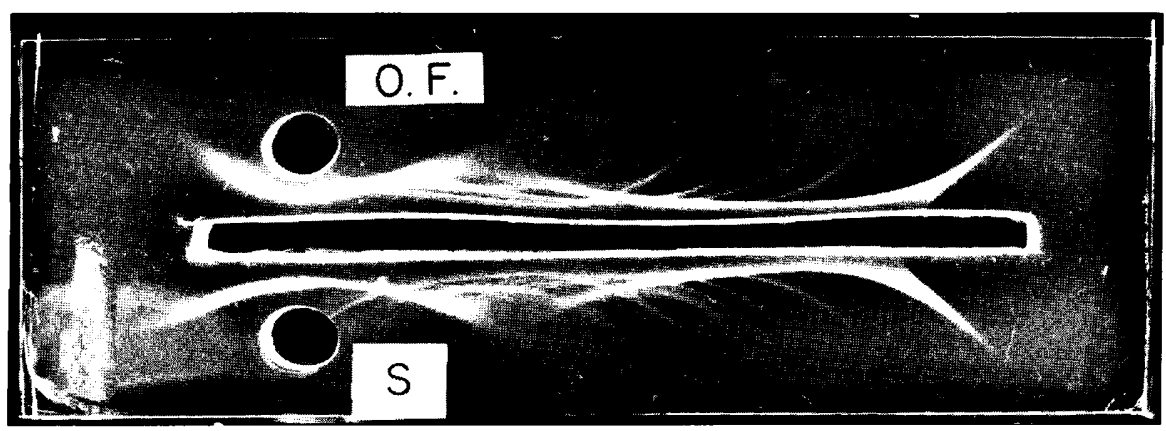

FIG. 2. Immunoelectrophoresis of rabbit oviducal fluid and serum. Conditions for clectrophoresis are described under Methods. S, $2 \mu 1$ of rabbit serum applied; O.F., $20 \mu$ of oviducal fluid applied. 'The trough contained $30 \mu \mathrm{l}$ of rabbit antisera. 

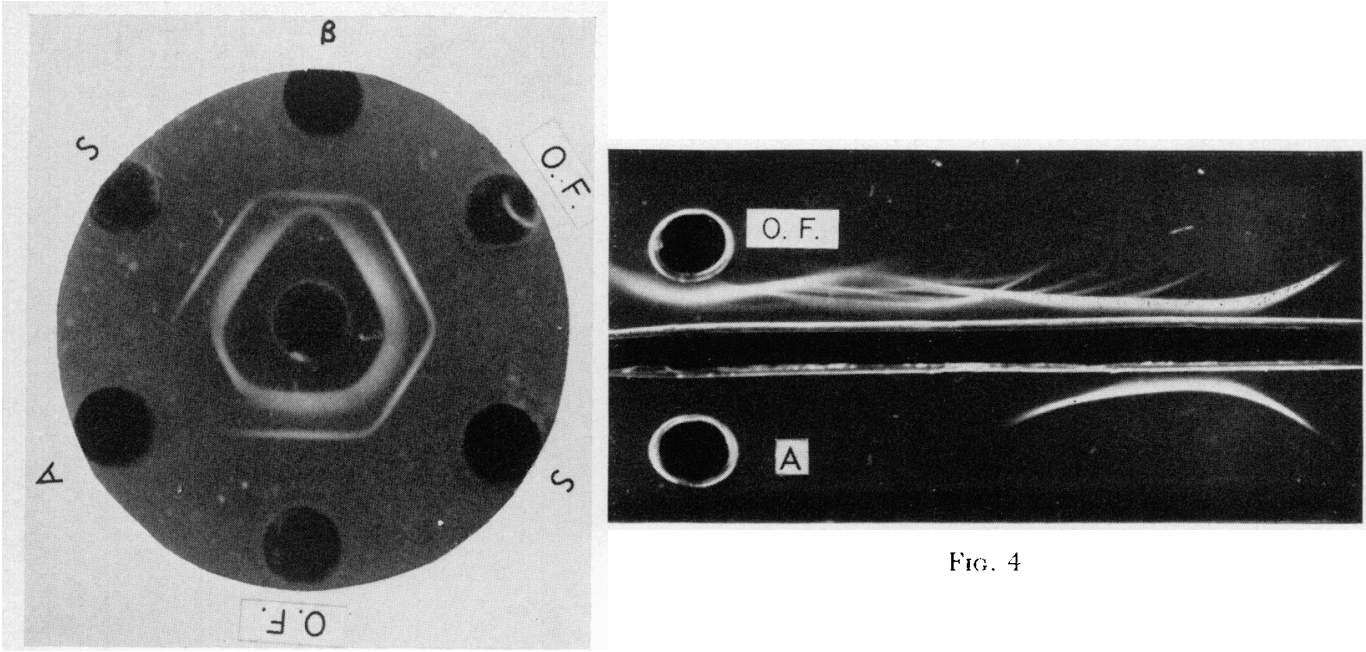

Fis. 4

list: 3

Iir;. 3. I)ouble-diffusion study of oviducal fluid, serum, albumin and $\beta$-globulins. Conditions for double-diffusion are deseribed under Methods. Centre well, $20 \mu l$ antirabbit serum; $A, 5 \mu 1$ of $3 \mathrm{mg} / \mathrm{ml}$ albumin solution; $B, 15 \mu \mathrm{l}$ of $3 \mathrm{mg} / \mathrm{ml} \beta$-globulin solution; $\mathrm{S} .3 \mu \mathrm{l}$ of serum; O. $1.20 \mu \mathrm{l}$ of oviducal fluid.

Firs. 4. Immunoelectrophoresis of oviducal fluid and albumin. Conditions for electrophoresis are described under Methods. ().F. $20 \mu \mathrm{l}$ ol oviducal fluid applied. A. $5 \mu$ of a $3 \cdot 0 \mathrm{mg} / \mathrm{ml}$ solution of rabbit albumin. The trough contained $30 \mu 1$ of rabbit antisera.
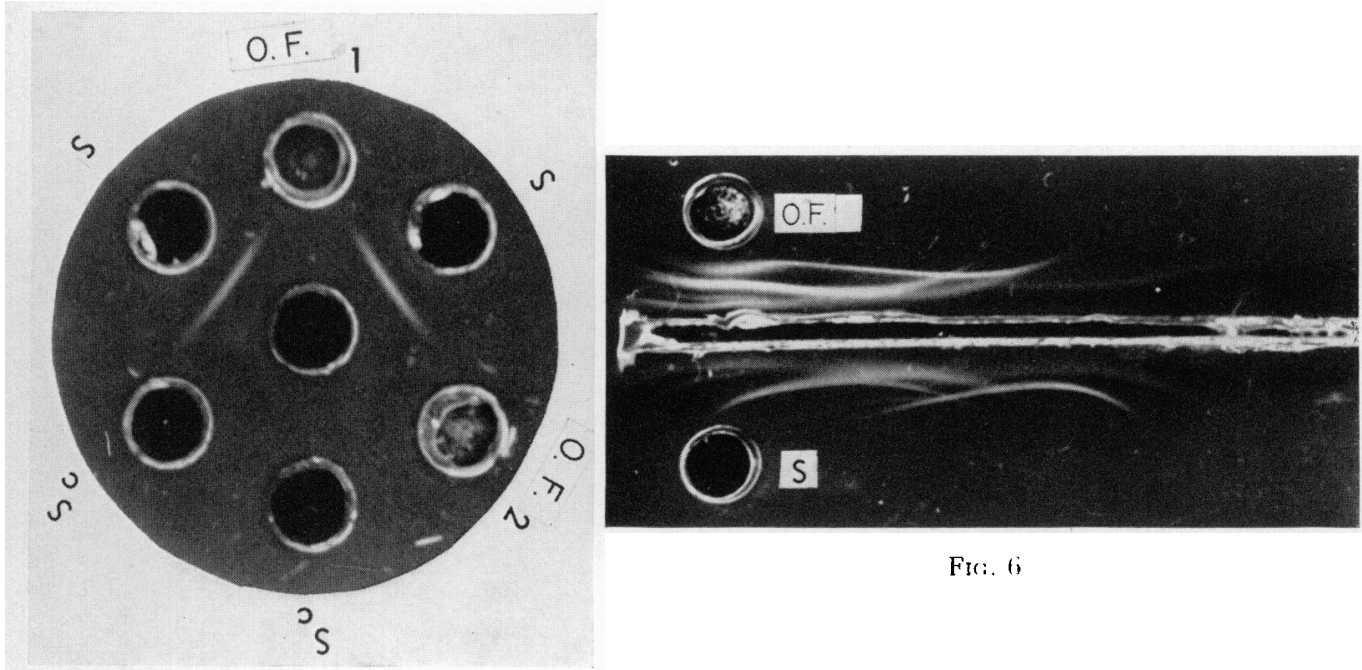

FIr. 1

liti: $;$

Fir: 3. Double-difusion study of widucal fluid, serum and Y-ADH. Centre well, $\mathrm{Y}-\Lambda \mathrm{DH} 20 \mu \mathrm{l}$ of $1 \mathrm{mg} / \mathrm{ml}$ solution; $\mathrm{S}_{\mathrm{c}}$, control serum before immunization with $\mathrm{Y}-\mathrm{ND} \mathrm{H}$ $(5 \mu \mathrm{l})$; $\mathrm{S}$, rabbit serum after immunization $(5 \mu \mathrm{s}) ; \mathrm{O} . \mathrm{F} \cdot 1$, oviducal fluid $(20 \mu \mathrm{l})$ containing $15 \mathrm{mg} / \mathrm{ml}$ protein; O.F.2, oviducal fluid $(20 \mu \mathrm{l})$ containing $60 \mathrm{mg} / \mathrm{ml}$ protein. Fic: 6 . Inmunoelectrophoresis of serum and oviducal fluid with antioviducal fluid. The conditions of immunoelectrophoresis are described under Methods. $0 . \mathrm{F} ., 30 \mu \mathrm{l}$ of a sample applied with $40 \mathrm{mg} / \mathrm{ml}$ of protein; $\$, 2 \mu l$ of rabbit serum. The trough rontained 30 pl of chicken anti-oviducal fluid. 
Fig. 6). This confirmed the presence of common antigens in both serum and fluid. The oviducal fluid reacted with anti-rabbit oviducal fluid to produce more precipitin bands in the beta-gamma region than were seen in the reaction with serum. No anti-albumin could be detected and very few anti- $\alpha$-globulins were produced. This apparently was due to a poor immunological response in the hen. Similarly, the presence of additional, unknown proteins of the fluid may have been missed if they serve as poor antigens in the fowl. These results are in agreement with previous disc gel electrophoresis (Pl. 1, Fig. 1a, b) and confirm that there are protein species in the oviducal fluid which are not present in serum.

\section{DISCUSSION}

The present studies reveal that oviducal fluid of rabbits contains many serum proteins and, additionally, several proteins not found in serum. Most of the total protein would seem to come from the serum although not all of the serum proteins can be detected in the fluid. Albumin is by far the most prominent protein of the rabbit oviducal fluid.

The observed differences in the protein populations in serum and oviducal fluid in these experiments may be minimal. Minor protein components may not be detectable at the concentrations employed in these experiments. Larger quantities of proteins in the disc gel experiments would result in overloading and masking of the lesser components. Thus, the actual differences of individual proteins in the two fluids may be very much greater than seen here.

Support for the view that processes other than transudation play a rôle in the formation of oviducal fluid comes from the experiments involving antibodies both to yeast alcohol dehydrogenase and to oviducal fluid proteins. Antibodies to rabbit oviducal fluid proteins formed in the hen were found to give more precipitin bands when allowed to react against oviducal fluid than against rabbit serum. It is difficult to estimate the number of special proteins in the rabbit oviducal fluid from these experiments. Several bands are evident in Pl. 2, Fig. 6 but others may have been missed because of titres that were too low for reaction or because of a poor antigenic response in the chicken.

Levels of yeast alcohol dehydrogenase antibody in the serum were first detected 3 weeks after intramuscular administration of the antigen, and serum levels were checked during a period of 10 weeks. During this time, however, no antibody appeared in the oviducal fluid. Whatever the mechanism(s) for protein transfer from the vascular compartment to the oviducal fluid, there must be a method for selection. It is probable that yeast alcohol dehydrogenase antibody comprises part of the $\gamma$-globulin fraction; and although proteins that migrate as $\gamma$-globulins have been detected in oviducal fluid, this component is absent.

Marcus \& Saravis (1965) and Marcus (1967) have reported that monkey oviducal fluid contains proteins with the mobility of albumin as well as $\alpha_{1}$, $\alpha_{2}, \beta$ - and $\gamma$-globulins. These authors also reported a decrease in the percentage composition of the $\gamma$-globulin fraction in the oviducal fluid compared to monkey serum. This oviducal fluid from the monkey was collected from doubly ligated oviducts after 7 days' accumulation and, therefore, represents 
an equilibrium. These authors reported no anti-oviducal fluid studies but based their conclusions about the proteins present on the reactions of oviducal fluid and anti-monkey serum.

To date, no rôle has been outlined for oviducal fluid proteins in the normal growth and development of fertilized rabbit eggs during their stay in the oviduct, though Krishnan \& Daniel $(1967,1968)$ have partially purified a protein ('blastokinin') from rabbit uteri which they found induced blastulation of rabbit morula and stimulated blastocyst development. These authors reported that ". . . maternal serum proteins did not promote comparable expansion of embryos of these stages and that highest concentrations [of blastokinin] are found at approximately 5 days".

More recently, a second uterine protein, 'uteroglobin', has been obtained from rabbit endometrial secretions (Beier, 1968). This material is also believed to be involved in blastocyst development. As with blastokinin, this protein was found only in pregnant female rabbits.

The present studies do not allow for quantification of the differences in oviducal fluid and serum. The significance of the present findings lies in the fact that the fluids differ in their composition and that oviducal fluid has detectable specific proteins. Thus, we believe, the fluid is neither a complete transudate nor a secretory product. The identification of specific oviducal fluid proteins and their rôle in development of the fertilized egg are under investigation.

\section{REFERENCES}

BeIER, H. M. (1968) Uteroglobin: A hormone-sensitive endometrial protein involved in blastocyst development. Biochim. biophys. Acta, 160, 289.

Bishop, D. W. (1956) Active secretion in the rabbit oviduct. Am. F. Physiol. 187, 347.

Brshop, D. W. (1957) Metabolic conditions within the oviduct of the rabbit. Int. J. Fert. $2,11$.

Blandau, R. J. (1961) Biology of eggs and implantation. In: Sex and Internal Secretions, 3rd edn, Vol. 2, p. 825. Ed. W. C. Young. Williams \& Wilkins, Baltimore, Maryland.

DAvis, B. J. (1964) Disc electrophoresis. II. Method and application to human serum proteins. Ann. N.X. Acad. Sci. 121, Art. 2, 404.

Grabar, P. \& Williams, C. A., JR (1955) Méthode immuno-électrophorétique d'analyse de mélanges de substances antigéniques. Biochim. biophys. Acta, 17, 67.

Hamner, C. E. \& Williams, W. L. (1963) Effect of the female reproductive tract on sperm metabolism in the rabbit and fowl. $\mathcal{F}$. Reprod. Fert. 5, 143.

Hamer, G. E. \& Williams, W. L. (1965) Composition of rabbit oviduct secretions. Fert. Steril. 16, 170.

Krishnan, R. S. \& Daniel, J. C., JR (1967) "Blastokinin": inducer and regulator of blastocyst development in the rabbit uterus. Science, N.Y. 158, 490.

Krishnan, R. S. \& Daniez, J. C., JR (1968) Composition of "blastokinin" from rabbit uterus. Biochim. biophys. Acta, 168, 579 .

Lowry, O. H., Rosebrough, N. J., Farr, A. L. \& Randall, R. J. (1951) Protein measurement with the Folin phenol reagent. F. biol. Chem. 193, 265.

Marcus, S. L. (1967) Observations on the origin of oviduct ftuid in the rhesus monkey. In: Proceedings of the Fifth World Congress on Fertility and Sterility, pp. 195-198. Eds. Björn Westin and Nils Wiquist. Excerpta Medica Foundation, New York.

Marcus, D. M. \& Grollman, A. P. (1966) Studies of blood group substances. F. Immun. 97, 867.

Marcus, S. L. \& Saravis, G. A. (1965) Oviduct fluid in the rhesus monkey. Fert. Steril. 16, 785.

Ouchterlony, O. (1953) Antigen-antibody reactions in gels. IV. Acta path. microbiol. scand. 32, 231.

Sobrero, A. J. (1963) Sperm migration in the female genital tract. In: Mechanisms Concerned with Conception, p. 187. Ed. Carl G. Hartman. Macmillan, New York.

VAllee, B. L. \& Hoch, F. L. (1955) Zinc, a component of yeast alcohol dehydrogenase. Proc. natn. Acad. Sci. U.S.A. 41, 327.

YARD, A. S., Juhasz, L. P. \& GRimes, R. M. (1969) Studies on the antifertility effect and metabolism of a new, postcoital, oral contraceptive, 2-methyl-3-ethyl-4-phenyl- $\Delta^{4}$-cyclohexene carboxylic acid, sodium salt (ORF-4563). F. Pharmac. exp. Ther. 167, 105. 